\title{
Kolobow 式膜型人工心肺の臨床使用経験
}

\author{
東京女子医科大学附属日本心臟血圧研究所

\begin{tabular}{|c|c|c|c|c|c|c|}
\hline ○佐藤 & 彰* & 坂本 & 高梨 & 吉則 ${ }^{* *}$ & 小柳 & 仁** \\
\hline 太田 & 諭* & 入山 & 龍野 & 勝彦** & 今井 & 康晴** \\
\hline 岸 & 三郎* & 上原吉三郎 ${ }^{* *}$ & 後藤 & 一雄** & 橋本 & 政明** \\
\hline
\end{tabular} \\ 国立横浜病院 心臟外科 \\ 横須賀 達也 \\ メディカル八千代田 \\ 増本 武司原新治
}

\section{はじめに}

当研究所において膜型人工肺の臨床使用が開始 されてすでに 3 年である.この間, 使用された膜型 肺は 250 例以上に達し（主として Landé-Edwards 型肺)，気泡型肺 ${ }^{13)}$ と並んで，その臨床的価值は 確実なものとなった、今回私達は Landé-Edwards 型肺》潜わる膜型肺として Kolobow 型肺を入手 する機会を得たので，動物実験および模擬生体を 作製して種々の膜面積において Data を検討した 結果 ${ }^{4)}$ ，臨床使用可能であるとの判断に立ち本年 (1976 年) 1 月より臨床使用を始めた.

今回私達が報告するのは，Landé-Edwards 型肺 および，現在使用している Kolobow 型肺と気泡 型肺（東京女子医大式）の利点および欠点や，当 研究所における使用方法を比較検討し報告する.

\section{機種，構造}

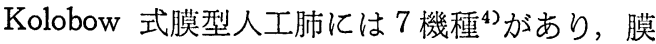
と血液およびガス接触面積が $0.4 \mathrm{~m}^{2}$ の Model 0400-1, 0.8 $\mathrm{m}^{2}$ の Model 0800-1, 1. $0 \mathrm{~m}^{2}$ の Model 1000-1, 1, $5 \mathrm{~m}^{2}$ の Model 1500-1, 2. $5 \mathrm{~m}^{2}$ の Model 2500-1, 3. $5 \mathrm{~m}^{2}$ の Model 3500-1, 4. $5 \mathrm{~m}^{2}$ の Model 4500-1 とがあり, 現在, 当研究所では $0.8 \mathrm{~m}^{2}$,

* 人工心肺

** 心臟外科
$1.5 \mathrm{~m}^{2} ， 2.5 \mathrm{~m}^{2} ， 3.5 \mathrm{~m}^{2}$ の 4 機種を臨床使用して いる. 充填液量は, $0.8 \mathrm{~m}^{2}$ で $80 \mathrm{ml}, 1.5 \mathrm{~m}^{2}$ で $170 \mathrm{ml}, 2.5 \mathrm{~m}^{2}$ で $330 \mathrm{ml}, 3.5 \mathrm{~m}^{2}$ で $450 \mathrm{ml}$ で あり，定格性能として，乙れらの機種の軽度低体 温時における対応患者重量は $0.8 \mathrm{~m}^{2}$ で 0 ～ $8 \mathrm{~kg}$ ， $1.5 \mathrm{~m}^{2}$ で $10 \sim 15 \mathrm{~kg}, 2.5 \mathrm{~m}^{2}$ で $16 \sim 35 \mathrm{~kg}, 3.5$ $\mathrm{m}^{2}$ で $36 \sim 65 \mathrm{~kg}$ である.

この人工肺の構造はポリプロピレン製の Spacer screen 2 枚の Silicone rubber membrane では さみ(図 1)，乙れらが一帯となったラセン状をし

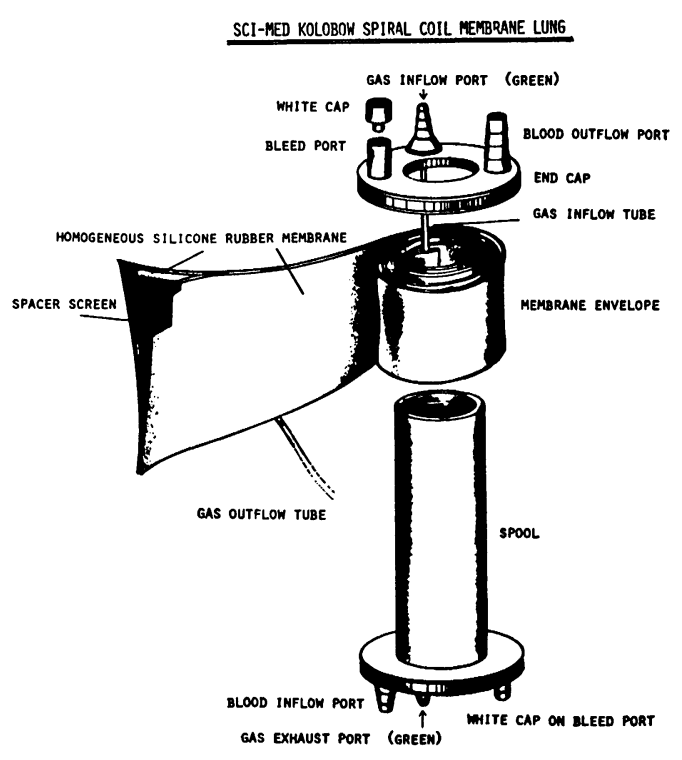

図 1 
た円筒型である，との 2 枚の Membrane の内側 を酸素が流れるようになっており，外側の带と带 の間を血液が $20 \mu \sim 40 \mu$ の厚さで流れるように 作製されている.

\section{体外循環回路}

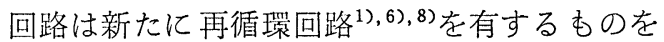
使用した。現在，体重 $10 \mathrm{~kg}$ 以下の患者には（図

\section{THE DRAWING: BLOOD FLOW CIRCUIT SET} WITH KOLOBOW MEMBRANE LUNG (1)

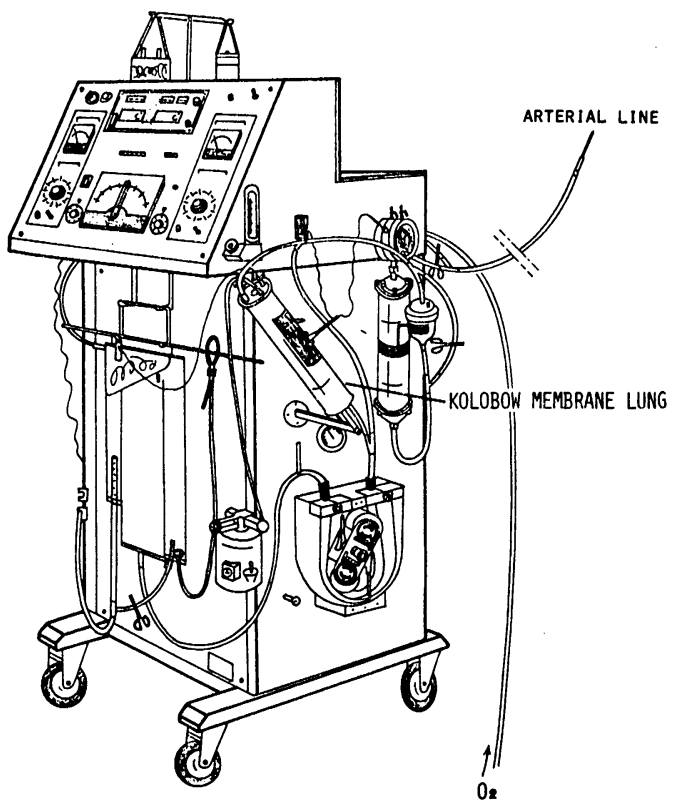

図 2

THE DRAWING: BLOOD FLOW CIRCUIT WITH KOLOBOW MEMBRANE LUNG (1)

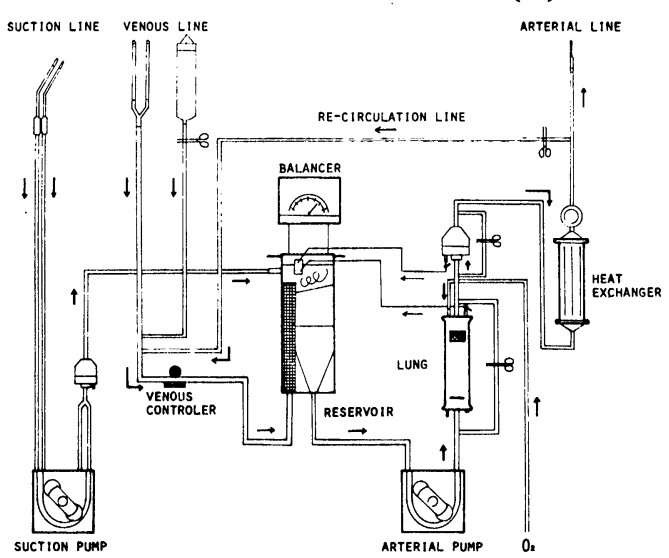

図 3
$2,3)$ のでとく $0.8 \mathrm{~m}^{2}$ の肺を送血側に装置し，体 重 $10 \mathrm{~kg}$ 以上の患者には（図 4,5）のでとく，脱 血側に肺を置き，ポンプにて吸引脱血している.

双方の回路においても肺内に Micro air が残存 するためポンプ圧を利用して，三方括栓を用いた 自動 Air 抜き装置を二力所，肺と Filter に用い た.

装置はトノクラ医科工業9), 10)の人工心肺装置で ポンプは送血，脱血，吸引ともに De-Bakey 型 Roller pump 使用し, 熱交換器は Braun-Harrison 型を使用している. 肺の取付方法は, 肺内部に残 存する Air 除去のため, 約 30 度程度の傾斜をも って取付け，構造上ラセン状になっているため，

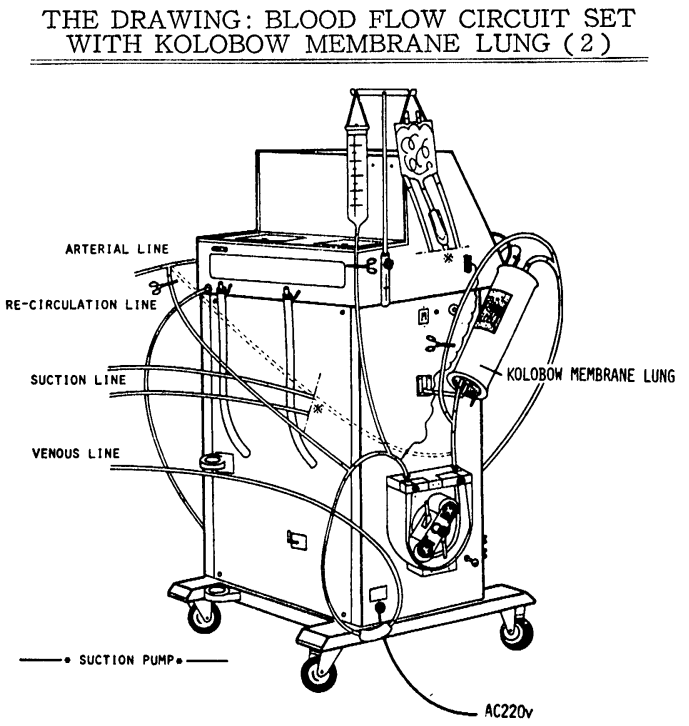

図 4

THE DRAWING: BLOOD FLOW CIRCUIT WITH KOLOBOW MEMBRANE LUNG (2)

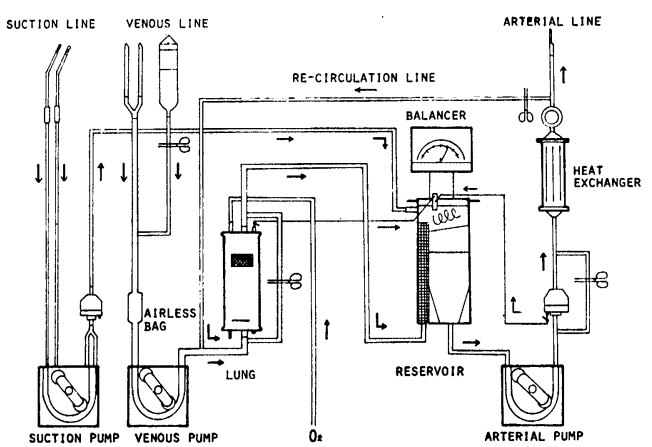

図 5 
重力落差方式では，血液を送り込めないので肺の 前に血液ポンプを置いている.

Kolobow 式膜型肺は Landé-Edwards 膜型肺 ${ }^{5)}$ のような塩化ナトリウム紛末の覆いがないため, Ethylene Oxyde Gas の除去以外は洗涤不要であ る.

\section{症 例}

今回は 50 症例の 臨床使用例を報告するが（図 6,7 ), 当研究所では現在（昭和 51 年 5 月 21 日現 在）年龄は 1 カ月〜 62 歳, 体重 $3.2 \mathrm{~kg} \sim 68 \mathrm{~kg}$, 疾患はVSD, ECD, T/F, TGA, MS, Angina その 他 104 例である. 灌流時間は 50 分〜250 分で灌流 量は $340 \mathrm{ml} / \mathrm{min} \sim 4800 \mathrm{ml} / \mathrm{min}$ である.

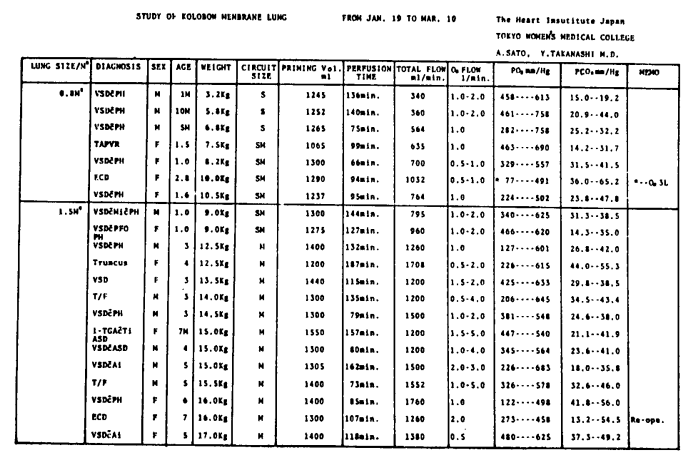

図 6

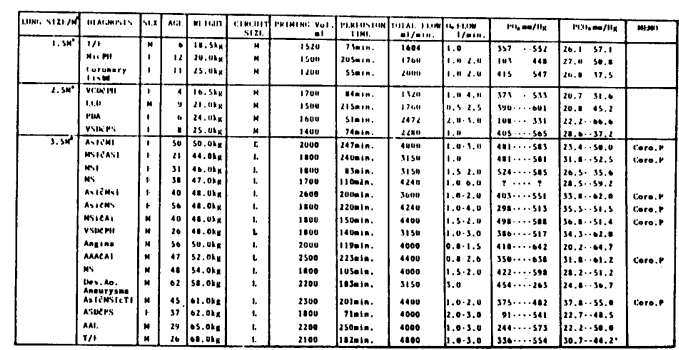

図 7

使用した Kolobow 式膜型人工肺を機種別に分 類すると $0.8 \mathrm{~m}^{2}-16$ 例, $1.5 \mathrm{~m}^{2}-36$ 例, $2.5 \mathrm{~m}^{2}$ 8 例, $3.5 \mathrm{~m}^{2}-44$ 例である.

\section{各種人工肺の比較検討}

1. 気泡型人工肺の特徽 ${ }^{11}$

(1) 回路 Set up に要する時間が極く短かい ため緊急時において便利である.（当研究所にて
は Set up 完了まで約 5 分である.)

(2) $\mathrm{PO}_{2}$ 調節が $\mathrm{O}_{2}$ 流量によってある程度可 能である.

2. Landé-Edwards 型人工肺の特徵 ${ }^{5)}$

（1）塩化ナトリウム粉末の洗滌に時間と労力 を費やす，（回路を組みたてた後，滅菌精製水に て 10 分間, 2 回洗涤し，10\% Maltos 液にて 10 分 間，1回洗滌をしたのち血液にて肺内に眝溜する $10 \%$ Maltos 液を肺外に押し出す過程を必要とす る.)

（2）回路内の気泡が完全に抜けない.

（3）充填血液量が多い.

3. Kolobow 型人工肺の特徵

（1）塩化ナトリウム粉末の覆いがないため, Ethylene Oxyde Gas の除去以外は洗涤が不要で ある. Kolobow 型肺は血液層が $20 \mu \sim 40 \mu$ 之薄 いため, Ethylene Oxyde Gas 除去洗滌後, 洗涤 液が完全に抜けず残溜があり，特に小児体外循環 の場合は稀釈率の点において留意を要する.

（2）肺内の気泡が完全に抜けないため，先の ごとく，自動 Air 抜き装置を肺の Bleed port に 装着している.

\section{各種人工肺の血液ガス分析}

今回は（図 8 ) のごとく, 体重が $9 \mathrm{~kg} \sim 15 \mathrm{~kg}$ で，灌流時間が 50 分程度で，ほぼ条件が一致す る, VSD の患者を多くの症例中より List up し て血液ガス分析の結果を比較検討してみた.

\begin{tabular}{|c|c|c|c|c|c|c|c|}
\hline DIAGNOSIS & $\mathrm{PH}$ & $\mathrm{PO}_{2}$ & $\mathrm{PCO}_{2}$ & $\mathrm{BE}$ & SB & $H T$ & TP \\
\hline \multirow{4}{*}{$\begin{array}{l}\text { VSD（15KG ) } \\
\text { BUBBLE TYPE } \\
\mathrm{O}_{2} \mathrm{FLOW}-. .4 \mathrm{~L}\end{array}$} & 7.401 & 217 & 39.4 & -5.1 & $2 n .1$ & 33 & 5.7 \\
\hline & 7.257 & 335 & 38.5 & $-9,5$ & 16.8 & 27 & 5.5 \\
\hline & 7.401 & 537 & 32.2 & -3.8 & 21.8 & $3 n$ & 5.2 \\
\hline & 7.497 & 501 & 32.3 & +2.1 & $2 \hbar .2$ & 28 & 5.1 \\
\hline \multirow{5}{*}{$\begin{array}{l}\text { VSD } \bar{c} P H(9 K G) \\
\text { L.E.M.O. TYPE } \\
3 M^{2} \\
0_{2} \text { FLOW-..4L }\end{array}$} & 7.563 & 81 & 29.2 & $+3,1$ & 27.1 & 29 & 4.3 \\
\hline & 7.484 & 303 & $38, n$ & +4.9 & 28.6 & $3 n$ & 4.2 \\
\hline & 7.453 & 347 & 44.2 & +5.8 & 29.5 & 32 & 4.2 \\
\hline & 7.478 & 241 & 42.8 & +7.0 & 30.9 & 31 & 4.2 \\
\hline & 7.428 & 82 & 42.1 & +2.9 & 26.9 & $3 n$ & $4 . n$ \\
\hline \multirow{2}{*}{ VSD $\bar{c} P H\left(12 K_{G}\right)$} & 7.577 & 578 & 19.3 & $-2,8$ & $22 . n$ & 22 & 5.5 \\
\hline & 7.616 & 620 & 23.2 & +3.8 & 27.6 & 28 & 5.3 \\
\hline \multirow{3}{*}{$\begin{array}{l}\text { KOLOBOW TYPE } \\
1.5 \mathrm{M}^{2} \\
\mathrm{O}_{2} \mathrm{FLOW} \ldots 1 \mathrm{~L} \\
\end{array}$} & 7.606 & 615 & 23.7 & +3.7 & 27.5 & 27 & 6,1 \\
\hline & 7.577 & 535 & $3 n .5$ & +6.4 & $3 n .2$ & 26 & $5 . n$ \\
\hline & 7.472 & 514 & 27.5 & +3.4 & 27,6 & 27 & 5.2 \\
\hline
\end{tabular}

図 8 


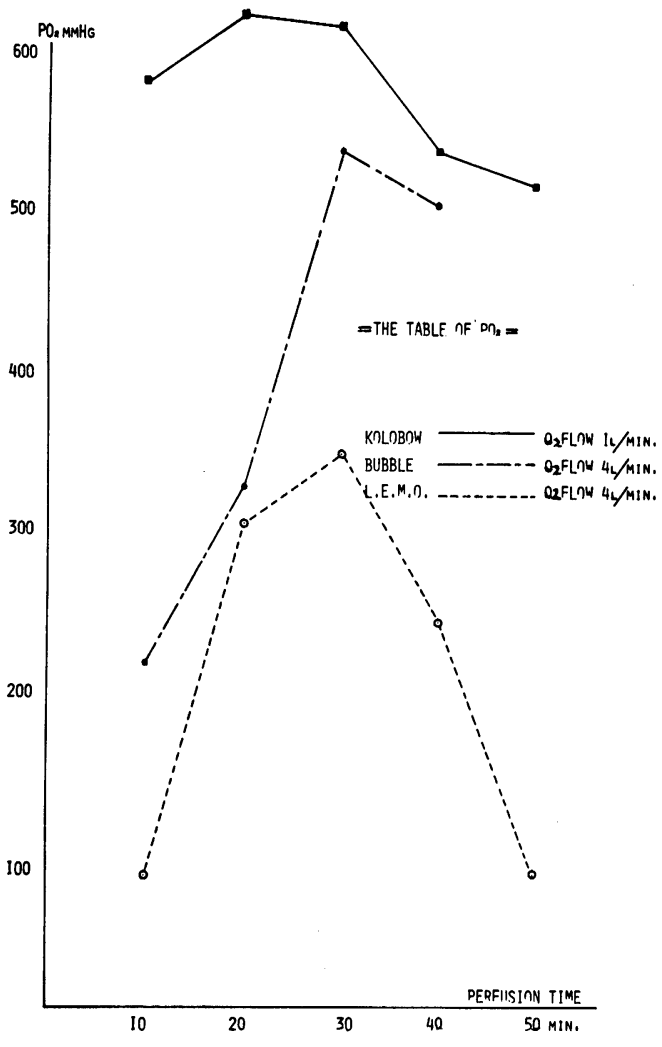

図 9

Kolobow 式人工肺の $\mathrm{PO}_{2}$ については（図 9) のごとく灌流開始から終了まで酸素流量は $1 l$ の 一定流量で, 流入した. 灌流開始 10 分には $\mathrm{PO}_{2}$ が， $578 \mathrm{mmHg}$ と高い值を示し，血液流量の増加 にあかかわらず，加温開始よりある程度の低下を みるが, 高い Lebel に括いて $100 \mathrm{mmHg}$ 内外の 差で比較的安定した值を示した. しかし酸素流量 が $1 l$ で $\mathrm{PO}_{2}$ が非常に高い值を示すため，その調 節に技術を要する.

気泡型肺 ${ }^{12), 13)}$ は灌流開始から終了まで酸素流 量は $4 l$ で流入したが，その $\mathrm{PO}_{2}$ は加温時にわ ずかの低下を観るが，比較的安定し，その $\mathrm{PO}_{2}$ 増 減は酸素流量の增減で補なえる. Landé-Edwards 型人工肺は気泡型と同じく $4 l$ の酸素流量をむっ て灌流した. 灌流開始 10 分では他の肺に比して $81 \mathrm{mmHg}$ と低い值を示し，序々に安定した值を 示したが，流量の増加と共に加温時からは急激に 酸素加能力が低下する傾向にあった.

$\mathrm{PCO}_{2}$ については(図 10)のでとく, 各肺につい

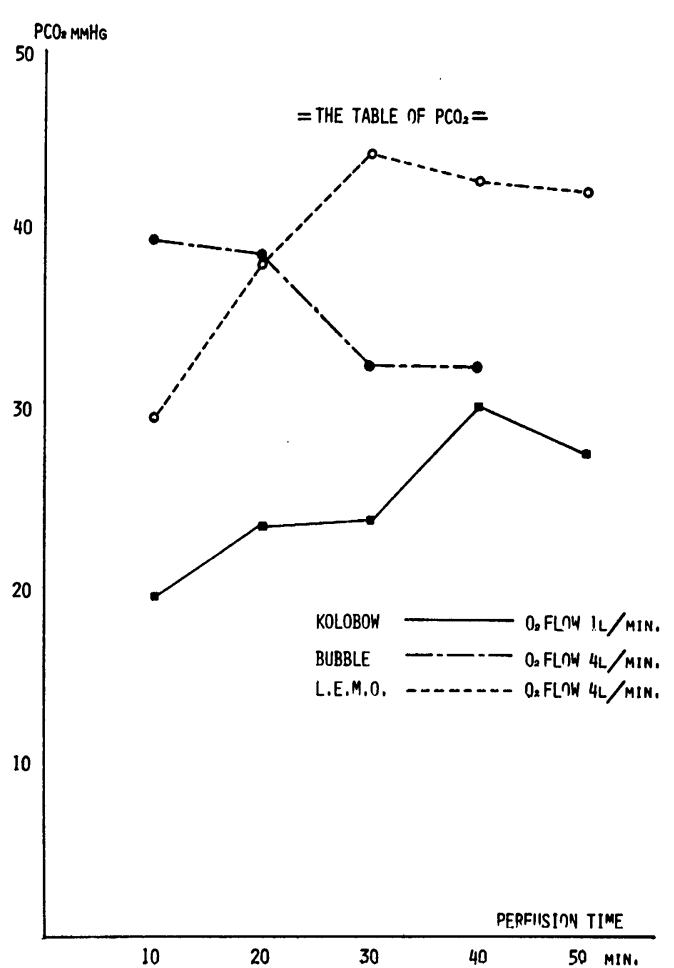

図 10

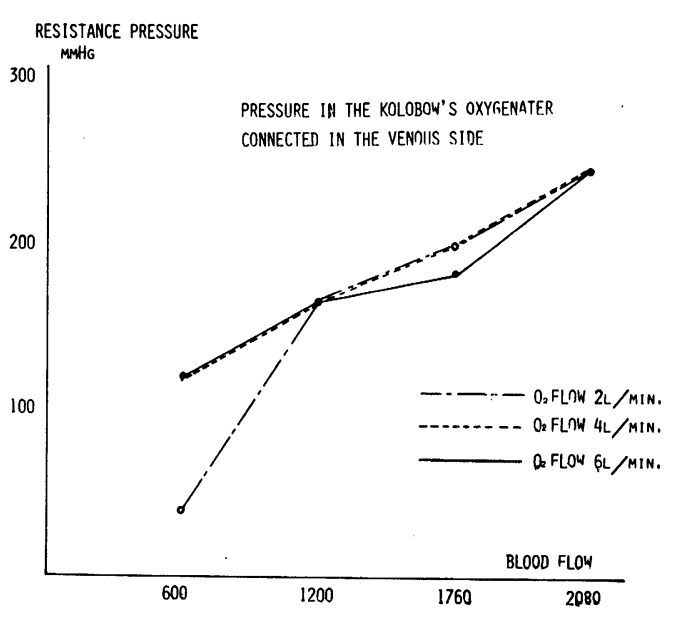

図 11

て前記のように同じ酸素流量下での比較である.

Kolobow 型人工肺は灌流開始 10 分で $19.3 \mathrm{mmHg}$ と非常に低い值を示し終了まで多少の増加がある が $10 \mathrm{mmHg}$ 程度で比較的安定している. 今回は 準備できなかったが，動脈側之静脈側の血液ガス 分析の比較検討の結果, $\mathrm{CO}_{2}$ の抜けが非常に良い 
ととが解った.

気泡型肺は, Kolobow 型肺の $\mathrm{PCO}_{2}$ よりもや や高い值を示したが，加温時においても増加の傾 向はみられず安定している. てれはその肺の構造 上から $\mathrm{CO}_{2}$ の抜けが良いと考えられる.

Landé-Edwards 型肺は他に比して高い值を示 し, $\mathrm{CO}_{2}$ の貯溜が増加してくるとその抜けが悪く なる。

次に（図 11)に示したでとく, Kolobow 型肺の内 部抵抗は他に比して高いということである. この グラフは肺の血液流入口に Manometer を設置し 血流量の変化に応じ，測定したものである. 酸素 流量 $2 l$ で血流量 $600 \mathrm{ml} / \mathrm{min}$ 時に, $40 \mathrm{mmHg}$ と 低いが血流量の増加とともに $1200 \mathrm{ml} / \mathrm{min}$ からは 酸素流量に無関係に，ほぼ一定の增加直線を描い た. Kolobow 肺 ${ }^{4}$ は構造上 $2000 \mathrm{mmHg}$ の加圧に 耐えるよう，作製されているのでグラフに示され たような值の範囲内では肺の破損の心配はない。 しかし灌流操作においては膜に余分な圧をかけな いように充分な注意を要する.

\section{結 語}

（1）常温および軽度低体温，超低体温下にお ける体外循環に際し，酸化装置として 1976 年 5 月 21 日までに Kolobow 式膜型人工肺を臨症例 104 例に使用し検討を加えた。

この膜型人工肺の体重別使用限界は灌流量60 $100 \mathrm{ml} / \mathrm{kg} / \mathrm{min}$ とした時, 当研究所では, $0.8 \mathrm{~m}^{2}$ では体重 $10 \mathrm{~kg}$ まで, $1.5 \mathrm{~m}^{2}$ では $20 \mathrm{~kg}$ まで, $2.5 \mathrm{~m}^{2}$ では $30 \mathrm{~kg}$ まで, $3.5 \mathrm{~m}^{2}$ は $30 \mathrm{~kg}$ 以上 の使用が可能であった.

（2）乙の人工肺はガス交換能の低下は認めら れず，他の人工肺に比して安定したガス交換能を
示した.

（3）溶血に関しては術中，吸引操作をおてな っているため, 人工肺自体による溶血は今回は検 討しなかった.

（4）Kolobow 型肺は少い充塡量, 膜の洗涤が 不用というととからも, 緊急時において，その使 用が充分可能と考えられる.

（5）肺内の血流抵抗が高いため，体外循環の 操作に打いて, 余分な加圧による膜の破損, 回路 の Leakeage 等に充分注意を要する.

(なおての論文は第 51 回医科器械学会大会に発表し たあのである.)

\section{参考文献}

1) The Ciba Collection 5 Heart: Netter

2) Alexamder's Care of the Patient in Surgery: fifth edition

3) Cardiovascular dynamics: Forth Edition Rushmer

4) Sci-Med Kolobow Membrane Lung Data and Instruction Sheets

5) Lande, A. J.et al. : Prolonged cardio-pulmonary support with a practical membrane oxygenator. Trans. Amer. Sol. Artif. Int. Organs, $16: 352,1970$.

6) Cardio-pulmonary perfusion: Charles C. Reed

7) 日本胸部外科学会雑誌 Vol. 21, No. 2

8）体外循環技術 Vol. 1, No. 1

9) 開心術のための人工心肺 藤倉一郎

10) 人工臟器 木本誠二

11）気泡型人工肺の改良一多孔板付気泡型人工肺の 開発, 医科器械学雑誌 Vol. 41, No. 6

12) 最近の Oxygenator; 呼吸之循環 Vol. 21 , No. 12

13) Disposable Sheet Oxygenator-1000 例の臨休 経験之㭘討; 榊原仟他, 胸部外科 Vol. 23 , No. 6 